\title{
A Reference Renaissance
}

\author{
Correspondence for Reference \& \\ User Services Quarterly should be \\ addressed to Editor Diane Zabel, \\ Schreyer Business Library, The Penn- \\ sylvania State University, 309 Paterno \\ Library, University Park, PA 16802; \\ e-mail:dxz2@psu.edu.
}

$\mathbf{T}$ wo events this past August prompted me to think more about reference services than I have for some time. The first was being interviewed by the editor-in-chief of Arugus, a journal published by the Corporation of Professional Librarians of Quebec. I was asked to respond to several questions about the future of reference services for a forthcoming thematic issue on this topic. The second event was a two-day Penn State University Libraries reference retreat, an in-house workshop attended by approximately eighty-five librarians and staff members (with additional virtual attendees). I am using this space as a forum to share what I learned from my innovative colleagues and the incomparable Marie Radford, the keynote speaker and workshop facilitator.

Radford, an associate professor in the Rutgers University School of Communication, Information and Library Studies, is well-known to many RUSQ readers. She is a leading researcher on the topic of interpersonal communication in face-to-face and virtual reference encounters. In addition to being a highly sought-after speaker, she has published widely on virtual reference. Our understanding of the latter will be greatly enriched by her ongoing study of virtual reference services. She is the co-principal investigator of "Seeking Synchronicity: Evaluating Virtual Reference Services from User, Non-User, and Librarian Perspectives," a study funded by a grant from the Institute of Museum and Library Services. Readers wanting to track Radford and Lynn Silipigni Connaway's (the other principal investigator) progress on this important study may do so by visiting Radford's page. ${ }^{1}$

I was struck by one of the comments made by associate dean Sally Kalin in her message welcoming retreat participants. She notes a resurgence of interest in reference, reflected in part by large and enthusiastic audiences at reference-related programs at recent professional conferences. The standing-room-only crowd at the 2007 RUSA President's Program on the future of reference and user services certainly confirms this observation. ${ }^{2}$ Kalin's hypothesis is that more libraries are recognizing that the provision of excellent public service is essential to the future of libraries. Regardless of how one feels about referring to patrons as customers, the delivery of quality reference service is good customer service.

Subsequent speakers described the current reference environment at Penn State University Libraries. Because our university is a highly complex, multisite institution, the reference climate varies considerably based on location. ${ }^{3}$ At University Park, reference statistics have been flat for the past three years after a downward trend. Librarians are spending considerably less time on desk, relying more heavily on stu- 
dents and other part-time reference assistants to staff desks. However, during this same period, there has been a marked increase in instruction and liaison activities, resulting in more direct (that is, bypassing the reference desk) reference encounters between patrons and subject specialists. Some samples of reference questions answered by Penn State librarians provided evidence that librarians are, indeed, answering more complex questions. While ready reference transactions have decreased, users continue to turn to librarians when the Internet fails them. Penn State librarians also are making a concerted effort to connect to users by providing both roving reference inside the library and off-site reference assistance. In sum, personal contact with users seems to be increasing. At many locations outside University Park, librarians are very involved in the daily life of faculty and students. In general, students and part-time reference assistants are relied upon less frequently to provide reference service. Throughout the Penn State system, reference is being delivered face-to-face and virtually (using e-mail, instant messaging [IM], chat, Facebook, and Second Life). This discussion of our reference climate highlighted one important shortcoming. The statistics we collect fail to capture this varied and complex reference activity.

In her keynote address, Radford reiterated that it is critical that we record our interactions with users, especially as we are not having less user contact. ${ }^{4}$ In describing the current and future reference environment, Radford noted that users born between 1979 and 1994 are experiential learners who like to be engaged. They also want services that are customized and personalized. While they are confident of their ability to find information, research indicates that they are not necessarily adept in doing so. Radford offered great concrete tips for meeting their needs, from promoting phone reference (have students enter the reference desk number on their cell phone), to offering instruction on searching Google. While there may be a generational gap between library staff and users, Radford cautioned that there also may be generational differences between those providing reference service. While younger librarians may have stronger technology skills, they may lack the depth of experience and knowledge of resources possessed by more experienced colleagues. Consequently, she recommended that libraries pair up librarians from different generations.

Radford reinforced these differences in expectations between millennial users and librarians during her lively presentation on communication strategies on day two of the retreat. ${ }^{5}$ While providing excellent suggestions for facilitating communication (in both face-to-face and virtual reference encounters), Radford reminded us that the "RUSA Guidelines for Behavioral Performance of Reference and Information Service Providers," offer a framework for practice. ${ }^{6}$

One of the most interesting aspects of this retreat was the concise lightning reports on programs and initiatives. The term "lightning reports" truly conveys the fast-paced experiments that are going on across our library system. These reports profiled a range of activities that Penn State librarians are currently engaged in: Facebook and other social networking tools, Second Life, virtual reference service, Meebo (a Web site that allows you to monitor multiple IM accounts at the same time), use of library-related widgets to create an undergraduate research portal, roving services, outreach services, and the creation of a portal for patrons using mobile technologies. Details about some of these initiatives can be found on individual Web pages. ${ }^{7}$ In addition to these brief sessions, hour-long sessions were conducted on information trapping (guidance on how to use RSS feeds and journal alerts to build a personal research desktop) and methodologies and tools for reference evaluation and assessment.

No workshop would be complete without breakout sessions. Participants could select from the following sessions: "Is the Reference Desk Dead?" "Assessment: Measuring the Quality and Impact of Reference Services," "Library As Place," and "Training Issues in Reference." Retreat planners did an outstanding job of keeping breakout sessions focused by providing each group with a list of four or five discussion questions. ${ }^{8}$ I attended the breakout session "Library As Place," which centered around the following topics: creating a social as well as a study and research space; advantages and disadvantages of the information commons model; the role of cafés and coffee shops (do they add or detract from a library's mission?); and strategies for marketing the library to the broader Penn State community. We concluded that academic libraries have become multifunctional spaces (and this is a good thing). Some of the initiatives that we are rolling out (such as the creation of a leisure reading collection at University Park) are rooted in our past. The archivist in this group informed us that decades ago, our library had sponsored a student contest for best personal library.

What did Penn State librarians learn after two days? We were pleased by our diverse approaches to reference. At the wrap-up session, Radford reminded us that we need to count the same thing at every service point, that assessment is an every day activity, training is crucial, and that we need to market our services more aggressively. Participants were asked to comment on one or two things before leaving the workshop. One anonymous comment that has remained with me is, "I'm glad reference is back!" Given the innovative approaches being adopted by many of my colleagues (and mirrored nationally), I will venture that reference is experiencing a regeneration, a reference renaissance. Within a week of the retreat, I joined Facebook and established an iGoogle account so I could create my own research portal. I am excited for classes to begin this fall so I can invite students to be my friend on Facebook and to demonstrate how easy it is to create a personal research portal. Finally, I am heartened by Radford's sage advice: "We are in control of inventing the future."

\section{References and Notes}

1. More information about the "Seeking Synchronicity" study and Radford's prolific research and presentation record can be found on Radfords' Web page, www.scils.rutgers.edu/ mradford (accessed Aug. 23, 2007). 


\section{FROM THE EDITOR}

2. The 2007 RUSA President's Program was titled "Time Odyssey: Visions of Reference and User Services." If you missed it, podcasts from this program are available from RUSA's Web site, www.ala .org/ala/rusa/rusapubs/pastpresidentpro/2007abc/ac2007prg.htm (accessed Aug. 23, 2007).

3. Penn State University Libraries serves 84,000 students and 6,000 faculty. The University Libraries comprises thirty-eight libraries located at University Park and twenty-three campuses. In terms of staffing, there are 157 librarians and professional staff, 321 support staff, and 98 FTE student assistants. Librarians have full faculty status.

4. Marie Radford, "Challenges for Reference Excellence: Realities and Possibilities," keynote address presented at the Penn State University Libraries Reference Retreat, August 1-2, 2007, University Park, Pennsylvania.

5. Marie Radford, "Strategies for Effective Communication and Service Excellence," workshop presented at the Penn State University Libraries Reference Retreat, August 1-2, 2007, University Park, Pa.

6. Reference and User Services Association, "Guidelines for Behavioral Performance of Reference and Information Service Providers," www.ala.org/ala/rusa/rusaprotools/referenceguide/guidelines behavioral.htm (accessed Aug. 23, 2007).

7. Alexia Hudson, a reference librarian at the Penn State Great Valley Library, is leading the way as a reference librarian in a virtual world. Her participation in Penn State's Second Life initiatives are chronicled in these recent news stories: "Program Allows Students to Simulate Life at PSU," The Daily Collegian Online, July 31, 2007, www.collegian.psu.edu/archive/2007/07/31/program_allows _students_to_sim.aspx (accessed Aug. 23, 2007); "Next Step in Virtual Reference," Interview 1, no. 15 (Apr. 16-22, 2007), www.libraries.psu.edu/news/interview/Interview04162007.pdf (accessed Aug. 23, 2007); "What Is Penn State Doing in Second Life?: Penn State Virtual Worlds," http://ets.tlt.psu.edu/virtual worlds/node/216 (accessed Aug. 23, 2007). The Thun Library at Penn State Berks serves up reference in a fun way by using a real hotdog cart to provide mobile library service. More information (including photographs) about this clever marketing strategy can be found at "The Ask Cart with the Library Dude!" www.libraries .psu.edu/berks/cart.html (accessed Aug. 23, 2007). Nicola Cecchino, assistant librarian at Penn State's George T. Harrell Library, has created an excellent mobile technologies portal to serve medical students. More information about this portal (including a link to Cecchino's blog) can be found at "Mobile Technologies Portal," www.hmc.psu.edu/library/eresources/pdal.htm (accessed Aug. 23, 2007).

8. Much credit is due to the reference retreat planning committee cochaired by Laurie Probst and Sam Stormont. I encourage readers to contact Sam Stormont, head librarian at Penn State Abington Library, directly (srs29@psu.edu) if they would like more details about Penn State's reference retreat.

9. Radford, "Challenges for Reference Excellence." 